\title{
Serum biomarkers in severe paediatric traumatic brain injury-a narrative review
}

\author{
Anusha Ganeshalingham, John Beca \\ Paediatric Intensive Care Unit, Starship Children's Hospital, Auckland, New Zealand \\ Contributions: (I) Conception and design: Both authors; (II) Administrative support: A Ganeshalingham; (III) Provision of study materials or patients: \\ A Ganeshalingham; (IV) Collection and assembly of data: Both authors; (V) Data analysis and interpretation: A Ganeshalingham; (VI) Manuscript \\ writing: Both authors; (VII) Final approval of manuscript: Both authors. \\ Correspondence to: Dr. Anusha Ganeshalingham. Paediatric Intensive Care Unit, Starship Children's Hospital, Park Road, Auckland, New Zealand. \\ Email: anushag@adhb.govt.nz.
}

\begin{abstract}
Severe traumatic brain injury continues to present complex management and prediction challenges for the clinician. While there is some evidence that better systems of care can improve outcome, multiple multi-centre randomised controlled trials of specific therapies have consistently failed to show benefit. In addition, clinicians are challenged in attempting to accurately predict which children will recover well and which children will have severe and persisting neurocognitive deficits. Traumatic brain injury is vastly heterogeneous and so it is not surprising that one therapy or approach, when applied to a mixed cohort of children in a clinical trial setting, has yielded disappointing results. Children with severe traumatic brain injury have vastly different brain injury pathologies of widely varying severity, in any number of anatomical locations at what may be disparate stages of brain development. This heterogeneity may also explain why clinicians are unable to accurately predict outcome. Biomarkers are objective molecular signatures of injury that are released following traumatic brain injury and may represent a way of unifying the heterogeneity of traumatic brain injury into a single biosignature. Biomarkers hold promise to diagnose brain injury severity, guide intervention selection for clinical trials, or provide vital prognostic information so that early intervention and rehabilitation can be planned much earlier in the course of a child's recovery. Serum S100B and serum NSE levels show promise as a diagnostic tool with biomarker levels significantly higher in children with severe TBI including children with inflicted and non-inflicted head injury. Serum S100B and serum NSE also show promise as a predictor of neurodevelopmental outcome. The role of biomarkers in traumatic brain injury is an evolving field with the potential for clinical application within the next few years.
\end{abstract}

Keywords: Biomarkers; brain injuries; Glasgow outcome score; intensive care unit; pediatrics

Submitted Nov 13, 2020. Accepted for publication May 14, 2021.

doi: $10.21037 /$ tp-20-386

View this article at: https://dx.doi.org/10.21037/tp-20-386

\section{Introduction}

Traumatic brain injury is the commonest cause of death and disability amongst children greater than one year of age (1) and continues to present complex management and prediction challenges for the clinician. Traumatic brain injury is commonly classified into mild [Glasgow Coma Score (GCS) 13-15], moderate (GCS 9-12) or severe (GCS 3-8) based on the GCS. TBI should not be viewed as a single pathophysiological event, but a cascade that involves two separate injury phases, primary and secondary (2). Primary brain injury occurs at the time of the initial impact and results directly from forces generated causing injury to the physical structures of the brain. The physical structures of the brain include neurons, neural stem cells, glial cells and blood vessels. A typical neuron consists of a cell body, axon and dendrites and is generated by neural stem cells during childhood. Glial cells are non-neuronal cells that 
maintain homeostasis, form myelin and provide support and protection for neurons. In the central nervous system, glial cells include oligodendrocytes, astrocytes, ependymal cells and microglia.

The physical structures of the brain are closely protected and shielded from the systemic compartment by two separate barriers, the blood-brain barrier and the blood-cerebrospinal barrier. Therefore, under normal circumstances, proteins originating from neurons and glial cells are rarely detectable in blood. If there is disruption to either or both of these barriers following trauma, proteins may extravasate across the disrupted barriers and result in leakage into the blood or CSF following impact.

Secondary brain injury is the result of a pathophysiologic cascade of events that occurs in the seconds, minutes, and days to weeks following the primary brain injury (3). There are two distinct types of secondary brain injury. The first is the endogenous cellular, biochemical or molecular cascades that are released in the secondary injury (or repair) response and are associated with (I) ischaemia and energy failure; (II) excitotoxicity; (III) inflammation; (IV) direct tissue disruption; and (V) axonal injury (3).

The second, occurs in parallel and results from secondary insults in critically ill children in the field, emergency room or paediatric intensive care unit. These secondary insults produce adverse consequences on a central nervous system that is at increased vulnerability after TBI. The primary goal of neurointensive care is the prevention of factors that promote this form of secondary brain injury such as hypoxia, hypotension, intracranial hypertension, hypercarbia, hyperglycaemia or hypoglycaemia, electrolyte abnormalities, seizures and hyperthermia (4). Children with severe TBI still present complex management and outcome prediction challenges for the paediatric intensivist, despite decades of investigation.

\section{Current management \& why TBI trials fail}

Current principles for the management of children with severe TBI are contained in "Guidelines for the Management of Pediatric Severe Traumatic Brain Injury" published by the Brain Trauma Foundation (5). These evidence-based guidelines review all of the key goals and therapies. They were first published in 2003 (6) and subsequently updated in 2012 (7) and 2019 (5). The level of evidence informing these guidelines remains low. Of the 22 recommendations, there are none based on high quality evidence, only 3 based on moderate quality evidence (of which two are therapies to be avoided) and the remaining 19 are based on low quality evidence. The three largest randomised controlled trials for children with severe TBI were all performed to test the utility of early, prophylactic therapeutic hypothermia. All three failed to demonstrate a positive impact on the primary outcome (8-10).

In comparison to other fields of medicine, clinical trials in severe TBI pose complicated methodological challenges. Severe TBI is not one single disease entity, against which, one therapy or approach can be easily tested. This vastly heterogeneous environment will vary on a case by case basis that is dependent upon competing risk factors or comorbidities, a complex spectrum of brain injury pathologies, anatomical location, stage of brain development and maturity, widely varying severity of injury, and complicating factors such as extra-cranial injuries (causing additional hypoxia and hypotension) sustained during the traumatic event. It is, therefore, not surprising that one therapy or approach, when applied to a mixed cohort of children in a clinical trial setting, has yielded disappointing results.

A new path for brain injury research whereby children can be reliably stratified and selected for clinical trials, or provide vital prognostic information so that timely intervention and rehabilitation can be planned, is urgently required.

\section{Biomarkers}

A biomarker is 'a defined characteristic that is measured as an indicator of normal biological processes, pathogenic processes or responses to an exposure or intervention' (11). Thus, biomarkers are objective molecular signatures of markers of injury that are released into the bloodstream following traumatic brain injury and may represent a way of unifying the heterogeneity of TBI into a single biosignature.

In TBI, biomarkers can be used in one of two different ways. Firstly, biomarkers can be diagnostic. The FDA defines a diagnostic biomarker as "a biomarker that detects or confirms the presence of a disease or condition of interest, or identifies an individual with a subtype of disease (12)". In TBI, diagnostic biomarkers would have the potential to (I) diagnose children with TBI, including inflicted TBI, where a history of trauma may not be forthcoming; (II) discriminate between mild, moderate and severe TBI (III); reduce the need for ongoing neuroimaging; (IV) guide intervention selection and timing for clinical trials and ultimately (V) match therapy to pathophysiological patterns or biosignatures. Secondly, biomarkers can be prognostic. 
The FDA defines a prognostic biomarker as "a biomarker that is used to identify the likelihood of a clinical event, disease recurrence or disease progression in patients with a disease or medical condition of interest (12). In severe TBI, prognostic biomarkers would have the potential to (I) identify children at risk of neurocognitive deficits so that early intervention and rehabilitation can be planned much earlier in the course of a child's recovery or (II) identify children with a high likelihood of dying so that families can be counselled and prepared for a devastating outcome.

Brain biomarkers have attracted increasing attention with more than 90 different biomarkers studied in paediatric patients with TBI to date (13). Papa et al. (13) state that the ideal biomarker for traumatic brain injury would (I) have a high sensitivity and specificity for brain injury; (II) help stratify patients by severity of injury; (III) have a rapid appearance in accessible biological fluid; (IV) provide information about injury mechanisms; (V) have well-defined biokinetic properties; (VI) monitor progress of disease and response to treatment and (VII) predict functional outcomes. Biomarkers in traumatic brain injury may be sampled from blood, cerebrospinal fluid, brain interstitial fluid collected during brain microdialysis and most recently, saliva. Preliminary studies have shown that there is a correlation between salivary and serum S100B $(14,15)$. The greatest contribution to the peripheral signal most likely comes from those brain cell biomarkers derived from the brain interstitial fluid and cerebrospinal fluid. Clinical studies have appropriately targeted serum biomarkers which are readily available in all children. For example, cerebrospinal fluid may be accessible in those children with an extra ventricular drain. However, less than $10 \%$ of children will have an extra ventricular drain inserted (13). Cerebral microdialysis and salivary biomarkers are still largely research tools. For the purposes of this review, we will focus on serum biomarkers that have received the most attention in paediatric clinical studies of severe TBI.

\section{Types of biomarkers}

There are many ways to classify biomarkers-the approach taken in this article is to classify brain injury biomarkers based on the primary and secondary brain injury mechanisms.

\section{Primary brain injury: biomarkers of structural damage}

Biomarkers are released in response to damage to neurons and glial cells during primary brain injury. The processes covered by these biomarkers thus far includes dendritic, neuronal cell body and axonal injury, demyelination and astroglial injury and responses.

\section{S100B}

S100 calcium binding protein B, or S100B, is a protein of the S100 family and is a low molecular weight $(9-13 \mathrm{kDa})$, calcium binding protein. It is the most investigated brain injury biomarker in children to date (13). S100B is localised predominantly in astrocytic glial cells of the central nervous system and is specifically found in the cytoplasm and nucleus and thus will be present in brain interstitial fluid and cerebrospinal fluid. Small amounts of S100B are also found in peripheral locations including fat, skin, skeletal muscle, bone marrow (16) and abdominal organs (17). The biological half life is 2 hours and the elimination half-life is 30 minutes (18). There is a sharp rise in S100B levels within minutes after injury and levels decline rapidly over the next few hours and usually normalise within 24 hours (18).

Diagnostic Uses: There are 10 studies that have examined the diagnostic utility of S100B (19-28) in paediatric TBI (Table 1). S100B levels are significantly higher in children with TBI compared with healthy matched controls (19), higher in severe TBI compared with mild TBI (23) and higher in children with a lower presenting GCS (28). All but one study (24) found that S100B levels discriminated TBI severity.

Two studies examined S100B levels in children with inflicted and non-inflicted TBI $(21,22)$. S100B levels were higher when the two brain injury groups were combined, but S100B levels could not discriminate between inflicted TBI (iTIB) and non-inflicted TBI (nTBI). Both studies showed that there was a delayed peak in S100B levels in infants with iTBI.

S100B levels are significantly higher in children with an abnormal CT scan (25-27) but the predictive power of S100B for an abnormal CT scan is variable with AUC of 0.67 (95\% CI: 0.55-0.80) (25), 0.71 (95\% CI: 0.58-0.81) (27) and 0.93 (95\% CI: 0.873-0.987) (26). An MRI study showed that S100B levels could not discriminate between children with normal and abnormal scans (20).

Prognostic uses: There are 8 studies that have examined the predictive utility of S100B (24,28-34) and all found associations with various outcome measures (Table 1). A high S100B level at admission was associated with poor outcomes at hospital discharge (34). Outcome at 6 months post-injury, assessed using the Glasgow Outcome Score, 
Table 1 S100B

\begin{tabular}{|c|c|c|c|c|c|}
\hline Author & $\begin{array}{c}\text { Year } \\
\text { published }\end{array}$ & Study & Number of children & Biofluid \& timing & Main findings \\
\hline \multirow[t]{2}{*}{ Park et al. (28) } & 2019 & $\begin{array}{l}\text { Prospective, } \\
\text { observational } \\
\text { study }\end{array}$ & $\begin{array}{l}15 \text { children with TBI (9 in poor } \\
\text { group GCS <9 and } 6 \text { in good } \\
\text { group GCS } 10-15)\end{array}$ & $\begin{array}{l}\text { Serum S100B ( } \& \text { NSE) } \\
\text { within } 6 \text { hours of admission } \\
\text { and one week after trauma }\end{array}$ & $\begin{array}{l}\text { Diagnostic: high S100B level at } \\
\text { admission \& } 1 \text { week associated } \\
\text { with poor GCS group }\end{array}$ \\
\hline & & & & $\begin{array}{l}\text { Outcome assessed with } \\
\text { GOS at } 6 \text { months post } \\
\text { injury }\end{array}$ & $\begin{array}{l}\text { Prognostic: higher } \mathrm{S} 100 \mathrm{~B} \text { levels } \\
\text { at } 1 \text { week levels associated with } \\
\text { unfavourable outcome (GOS) } \\
(\mathrm{P}=0.009)\end{array}$ \\
\hline \multirow[t]{2}{*}{$\begin{array}{l}\text { Meshcheryakov } \\
\text { et al. (29) }\end{array}$} & 2018 & $\begin{array}{l}\text { Retrospective } \\
\text { study }\end{array}$ & $\begin{array}{l}169 \text { children with severe TBI } \\
\text { (65 children had NSE samples) }\end{array}$ & $\begin{array}{l}\text { Serum } \mathrm{S} 100 \mathrm{~B} \text { on days } 1-3 \text {, } \\
6-8,14-15 \text { and } 20-23\end{array}$ & Diagnostic: not assessed \\
\hline & & & & & $\begin{array}{l}\text { Prognostic: higher } \mathrm{S} 100 \mathrm{~B} \text { levels } \\
\text { in children who died compared to } \\
\text { those that survived ( } \mathrm{P}=0.038) \text {; did } \\
\text { not discriminate amongst } \\
\text { survivors with a good or poor } \\
\text { outcome (GOS) }\end{array}$ \\
\hline \multirow[t]{2}{*}{$\begin{array}{l}\text { Wilkinson } \\
\text { et al. (30) }\end{array}$} & 2016 & $\begin{array}{l}\text { Prospective, } \\
\text { observational } \\
\text { study }\end{array}$ & $\begin{array}{l}58 \text { children with mild/moderate/ } \\
\text { severe TBI }\end{array}$ & $\begin{array}{l}\text { Serum S100B ( } \& \text { NSE) } \\
\text { taken daily until arterial line } \\
\text { removed }\end{array}$ & Diagnostic: not assessed \\
\hline & & & & & $\begin{array}{l}\text { Prognostic: highest serum } \mathrm{S} 100 \mathrm{~B} \\
\text { level predictive of inattention at } \\
1 \text { year post injury (AUC } 0.7 \text { ); } \\
\text { paired baseline level of inattention } \\
\text { with trough serum level of } \mathrm{S} 100 \mathrm{~B} \\
\text { (AUC 0.94; } \mathrm{P}=0.036 \text { ) }\end{array}$ \\
\hline \multirow[t]{2}{*}{ Žurek et al. (31) } & 2012 & $\begin{array}{l}\text { Prospective, } \\
\text { observational } \\
\text { study }\end{array}$ & $\begin{array}{l}63 \text { children with mild/moderate/ } \\
\text { severe TBI }\end{array}$ & $\begin{array}{l}\text { Serum S100B, ( } \& \text { NSE, } \\
\text { GFAP) at admission and } \\
\text { every } 24 \text { hours for } 6 \text { days }\end{array}$ & Diagnostic: not assessed \\
\hline & & & & $\begin{array}{l}\text { Outcome measured with } \\
\text { GOS at } 6 \text { months post } \\
\text { injury }\end{array}$ & $\begin{array}{l}\text { Prognostic: Day } 0 \text { levels } \\
\text { predicted worse outcome or } \\
\text { death }(P<0.001)\end{array}$ \\
\hline \multirow[t]{3}{*}{ Hallén et al. (26) } & 2010 & $\begin{array}{l}\text { Prospective, } \\
\text { observational } \\
\text { study }\end{array}$ & $\begin{array}{l}111 \text { children with mild/moderate/ } \\
\text { severe TBI (group } 1=105 \text { with } \\
\text { no CT indicated or normal; group } \\
2=6 \text { with abnormal CT head }\end{array}$ & $\begin{array}{l}\text { Serum } \mathrm{S} 100 \mathrm{~B} \text { at admission } \\
\text { and } 6 \text { hours later }\end{array}$ & $\begin{array}{l}\text { Diagnostic: } \mathrm{S} 100 \mathrm{~B} \text { levels higher } \\
\text { in group } 2 \text { compared with group } 1 \\
\text { at admission }(\mathrm{P}<0.001) \text { and } \\
6 \text { hours after injury }(\mathrm{P}=0.016)\end{array}$ \\
\hline & & & & & $\begin{array}{l}\text { At a cut-off value of } 0.195 \mathrm{ug} / \mathrm{L} \text {, } \\
\text { AUC } 0.93 \text { with } 100 \% \text { sensitivity } \\
\text { and } 88 \% \text { specificity for } \\
\text { abnormal CT }\end{array}$ \\
\hline & & & & & Prognostic: not assessed \\
\hline
\end{tabular}

Table 1 (continued) 
Table 1 (continued)

\begin{tabular}{|c|c|c|c|c|c|}
\hline Author & $\begin{array}{c}\text { Year } \\
\text { published }\end{array}$ & Study & Number of children & Biofluid \& timing & Main findings \\
\hline $\begin{array}{l}\text { Bechtel } \\
\text { et al. (25) }\end{array}$ & 2009 & $\begin{array}{l}\text { Prospective } \\
\text { observational } \\
\text { study }\end{array}$ & $\begin{array}{l}152 \text { children with mild/moderate/ } \\
\text { severe TBI including } 24 \text { with } \mathrm{ICI} \\
\text { and } 128 \text { without } \mathrm{ICl} \text { on } \mathrm{CT} \text { head }\end{array}$ & $\begin{array}{l}\text { Serum S100B within } \\
6 \text { hours after injury }\end{array}$ & $\begin{array}{l}\text { Diagnostic: Serum S100B levels } \\
\text { were greater in children with } \mathrm{ICl} \\
\text { compared with those that did not } \\
(\mathrm{P}<0.001) \text { AUC to detect ICH was } \\
0.67 \text { (95\% Cl: } 0.55-0.8)\end{array}$ \\
\hline \multirow[t]{2}{*}{ Lo et al. (24) } & 2009 & $\begin{array}{l}\text { Prospective, } \\
\text { observational } \\
\text { study }\end{array}$ & $\begin{array}{l}28 \text { children with severe TBI (GCS } \\
<8) \text { \& non severe TBI }(\text { GCS >8) }\end{array}$ & $\begin{array}{l}\text { Serum S100B ( } \& 7 \text { other } \\
\text { biomarkers) at } 24 \text { h post } \\
\text { injury }\end{array}$ & $\begin{array}{l}\text { Diagnostic: Not elevated in } \\
\text { children with severe TBI; did not } \\
\text { discriminate between diffuse and } \\
\text { focal brain injury }\end{array}$ \\
\hline & & & & $\begin{array}{l}\text { Outcome assessed with } \\
\text { GOS at } 6 \text { months after } \\
\text { injury }\end{array}$ & $\begin{array}{l}\text { Prognostic: High } \mathrm{S} 100 \mathrm{~B} \text { levels on } \\
\text { day } 1 \text { predicted worse outcome } \\
(\mathrm{P}=0.015)\end{array}$ \\
\hline \multirow[t]{2}{*}{ Piazza et al. (23) } & 2007 & $\begin{array}{l}\text { Prospective, } \\
\text { observational } \\
\text { study }\end{array}$ & $\begin{array}{l}15 \text { children with mild/moderate/ } \\
\text { severe TBI }\end{array}$ & $\begin{array}{l}\text { Serum } \mathrm{S} 100 \mathrm{~B} \text { at admission } \\
\text { at after } 48 \text { hours }\end{array}$ & $\begin{array}{l}\text { Diagnostic: Higher S100B levels } \\
\text { in all children with TBI; levels } \\
\text { higher in severe TBI compared } \\
\text { with mild TBI }\end{array}$ \\
\hline & & & & $\begin{array}{l}\text { Outcome assessed at } \\
6 \text { months post injury with } \\
\text { GOS }\end{array}$ & $\begin{array}{l}\text { Predictive: could not be assessed } \\
\text { as all patients had a good } \\
\text { outcome }\end{array}$ \\
\hline \multirow[t]{2}{*}{$\begin{array}{l}\text { Berger } \\
\text { et al. (33) }\end{array}$} & 2007 & $\begin{array}{l}\text { Prospective, } \\
\text { case-control } \\
\text { study }\end{array}$ & $\begin{array}{l}152 \text { children with mild/moderate/ } \\
\text { severe } T B I\end{array}$ & $\begin{array}{l}\text { Serum S100B (NSE \& MBP) } \\
\text { at arrival, 12-24 hours after } \\
\text { injury and daily for } 5 \text { days } \\
\text { in severe TBI }\end{array}$ & Diagnostic: not assessed \\
\hline & & & & $\begin{array}{l}\text { Outcome assessed with } \\
\text { GOS score at varying time } \\
\text { points in first } 12 \text { months } \\
\text { after injury }\end{array}$ & $\begin{array}{l}\text { Predictive: Peak S100B level } \\
\text { associated with worse outcome } \\
\text { at all time points; Initial S100B } \\
\text { level associated with worse } \\
\text { outcome at all time points except } \\
\text { for at } 7-12 \text { months post injury }\end{array}$ \\
\hline \multirow[t]{2}{*}{$\begin{array}{l}\text { Berger } \\
\text { et al. (22) }\end{array}$} & 2006 & $\begin{array}{l}\text { Prospective, } \\
\text { case-control } \\
\text { study }\end{array}$ & $\begin{array}{l}14 \text { infants }(<1 \text { year) with inflicted } \\
\mathrm{TBI} ; 74 \text { healthy control }\end{array}$ & $\begin{array}{l}\text { Serum S100B (NSE \& MBP) } \\
\text { at admission }\end{array}$ & $\begin{array}{l}\text { Diagnostic: S100B not sensitive } \\
\text { or specific for children with iTBI }\end{array}$ \\
\hline & & & & & Prognostic: not assessed \\
\hline
\end{tabular}

Table 1 (continued) 
Table 1 (continued)

\begin{tabular}{|c|c|c|c|c|c|}
\hline Author & $\begin{array}{c}\text { Year } \\
\text { published }\end{array}$ & Study & Number of children & Biofluid \& timing & Main findings \\
\hline \multirow[t]{3}{*}{$\begin{array}{l}\text { Berger } \\
\text { et al. }(21)\end{array}$} & \multirow[t]{3}{*}{2005} & \multirow[t]{3}{*}{$\begin{array}{l}\text { Prospective, } \\
\text { case-control } \\
\text { study }\end{array}$} & \multirow[t]{3}{*}{$\begin{array}{l}56 \text { children with nTBI, } 44 \text { with } \\
\text { iTBI and } 64 \text { controls }\end{array}$} & \multirow[t]{3}{*}{$\begin{array}{l}\text { Serum S100B (NSE \& MBP) } \\
\text { at admission, 12-24 hours } \\
\text { after injury and daily for } \\
5 \text { days in severe TBI }\end{array}$} & $\begin{array}{l}\text { Diagnostic: Initial median serum } \\
\text { S100B significantly higher in } \\
\text { children with both forms of TBI } \\
\text { compared with controls }\end{array}$ \\
\hline & & & & & $\begin{array}{l}\text { No difference in initial or peak } \\
\text { S100B levels between children } \\
\text { with nTBI and iTBI; delayed peak } \\
\text { in S100B in iTBI compared with } \\
\text { controls }\end{array}$ \\
\hline & & & & & $\begin{array}{l}\text { Ability of initial S100B level to } \\
\text { diagnose TBI showed AUC } 0.82 \\
\text { with } 77 \% \text { sensitivity and } 72 \% \\
\text { specificity with a cut-off level of } \\
0.017 \mathrm{ng} / \mathrm{mL}\end{array}$ \\
\hline \multirow[t]{3}{*}{$\begin{array}{l}\text { Spinella } \\
\text { et al. (34) }\end{array}$} & \multirow[t]{3}{*}{2003} & \multirow[t]{3}{*}{$\begin{array}{l}\text { Prospective, } \\
\text { cohort study }\end{array}$} & \multirow[t]{3}{*}{$\begin{array}{l}27 \text { children with mild/moderate/ } \\
\text { severe TBI and } 136 \text { controls }\end{array}$} & \multirow[t]{3}{*}{$\begin{array}{l}\text { S100B within } 12 \text { hours of } \\
\text { injury \& PCPC at hospital } \\
\text { discharge }\end{array}$} & Diagnostic: not assessed \\
\hline & & & & & $\begin{array}{l}\text { Predictive: } \mathrm{S} 100 \mathrm{~B} \text { levels } \\
\text { predicted good versus poor } \\
\text { outcome at hospital discharge \& } \\
6 \text { months post injury }\end{array}$ \\
\hline & & & & & $\begin{array}{l}\text { A S100B level }>2.0 \mathrm{ug} / \mathrm{L} \\
\text { predicted poor outcome at } 6 \\
\text { months with sensitivity } 86 \% \text { and } \\
\text { specificity } 95 \% \text {. The ROC AUC } \\
\text { was } 0.94(+0.05)\end{array}$ \\
\hline \multirow{2}{*}{$\begin{array}{l}\text { Akhtar } \\
\text { et al. (20) }\end{array}$} & \multirow{2}{*}{2003} & \multirow{2}{*}{$\begin{array}{l}\text { Prospective } \\
\text { cohort study }\end{array}$} & \multirow{2}{*}{$\begin{array}{l}17 \text { children with mild/moderate/ } \\
\text { severe TBI with normal CT head }\end{array}$} & \multirow{2}{*}{$\begin{array}{l}\text { Serum S100B at } 6 \text { hours } \\
\text { and } 12 \text { hours post injury } \\
\text { and brain MRI within } \\
96 \text { hours following injury }\end{array}$} & $\begin{array}{l}\text { The mean } \mathrm{S} 100 \mathrm{~B} \text { level was higher } \\
\text { at both time points in children } \\
\text { with head and body trauma } \\
\text { compared with head alone } \\
(\mathrm{P}=0.018 \text { at } \mathrm{t} 1 \text { and } \mathrm{P}=0.025 \text { at } \mathrm{t} 2)\end{array}$ \\
\hline & & & & & Prognostic: not assessed \\
\hline \multirow[t]{3}{*}{$\begin{array}{l}\text { Berger } \\
\text { et al. (19) }\end{array}$} & \multirow[t]{3}{*}{2002} & \multirow[t]{3}{*}{$\begin{array}{l}\text { Prospective, } \\
\text { observational } \\
\text { study with } \\
\text { controls }\end{array}$} & \multirow[t]{3}{*}{$\begin{array}{l}45 \text { children with mild }(n=27) ; \\
\text { moderate }(n=6) \text { or severe }(n=12) \\
\text { TBI including } 2 \text { with iTBI; } 16 \\
\text { controls }\end{array}$} & \multirow[t]{3}{*}{$\begin{array}{l}\text { Serum S100B collected on } \\
\text { arrival to hospital and every } \\
12 \text { hours for } 5 \text { days }\end{array}$} & $\begin{array}{l}\text { Diagnostic: Higher mean } \mathrm{S} 100 \mathrm{~b} \\
\text { levels in patients with } \mathrm{TBI} \\
\text { compared with healthy controls } \\
(\mathrm{P}=0.008) \text {. }\end{array}$ \\
\hline & & & & & $\begin{array}{l}\text { S100B levels did not discriminate } \\
\text { between degrees of brain injury } \\
\text { severity, abnormal CT scan or } \\
\text { clinical features of vomiting, loss } \\
\text { of consciousness or } \\
\text { post-traumatic seizures }\end{array}$ \\
\hline & & & & & Prognostic: not assessed \\
\hline
\end{tabular}

Scientific literature (total papers $=16$; diagnostic papers $=10$ and prognostic papers $=8$ ). 
is associated with S100B levels at admission $(24,31,33,34)$ and at one week following injury (28). Time to peak S100B levels was associated with neurocognitive outcome (32). Two other studies found that admission levels were associated with poor outcome at 12 months post-injury $(30,33)$ and one found that admission S100B levels could discriminate between those that survived and those that died (29).

Limitations: The use of S100B is limited by its lack of specificity as extra-cerebral sources produce increases in levels of S100B in the setting of haemorrhagic shock, circulatory arrest or during cardiopulmonary bypass (35). The short halflife of S100B is also a limiting factor in acute TBI. Finally, S100B is not a useful marker in children less than 2 years of age due to high normative values in that age group (35-37).

Summary: S100B levels are significantly higher in children with TBI including children with inflicted and non-inflicted injury and there is limited evidence that higher levels are associated with increasing severity of TBI. S100B levels are not able to discriminate between inflicted and non-inflicted TBI but there is a longer time to peak S100B levels in infants with inflicted injury. This may reflect severity of the primary injury or increased secondary injury due to a delay in seeking medical attention. S100B levels are poor predictors of abnormal neuroimaging (CT and MRI). S100B levels shows promise as a predictor of outcome (GOS) at 6 months and 12 months after injury.

\section{Neuron specific enolase}

Enolases are glycolytic enzymes comprising three different subunits $(\alpha, \beta$ and $\gamma)$. Neuron-specific enolase (NSE) is a $78 \mathrm{kDa}$ dimeric, $\gamma$-isoenzyme that is located in the cytoplasm of central and peripheral neurons and neuroendocrine cells $(38,39)$. NSE can be detected in the blood within 6 hours after injury (36) and has a serum half-life of 24 hours $(28,36)$.

Diagnostic Uses: There are 5 studies that have examined the diagnostic utility of serum NSE $(21,22,24,28,40)$ (Table 2). Three studies showed diagnostic potential with stratification of TBI injury $(24,28,40)$. Serum NSE levels at admission and one week after injury were significantly higher in children with GCS $<9$ (poor group) compared with children with a GCS 10-15 (good group) (28). Similarly, children with a GCS $<12$ (poor group) had significantly higher mean levels of NSE when compared with children with a GCS $>12$ (good group) although higher levels were not associated with abnormalities on CT scan (40). One study found that NSE levels were two times higher in children with diffuse injury on CT scan compared to children with focal injuries $(\mathrm{P}=0.02)(24)$.
There are 2 studies that assessed NSE levels in children with inflicted versus non-inflicted TBI $(21,22)$. Initial NSE levels were significantly higher in children when the two brain injury groups were combined and predicted TBI with an AUC 0.85 with $71 \%$ sensitivity and $64 \%$ specificity by using an NSE concentration cut-off $11.36 \mathrm{ng} / \mathrm{mL}$ (21). However initial and peak NSE levels could not discriminate between iTBI and nTBI although the peak NSE level was significantly delayed in infants with iTBI (22). The second, smaller study used the same NSE concentration cut-off to achieve a sensitivity of $77 \%$ and specificity of $66 \%$ (21).

Prognostic uses: There are 9 studies that have examined the predictive value of NSE for outcome $(24,28-33,41,42)$ (Table 2). NSE levels taken within 24 hours of arrival to hospital were predictive of worse outcome as measured on the GOS at hospital discharge in one study (42), at 6 months in 4 studies $(24,28,31,32)$ and at varying time points in the first year in another study (33). NSE levels taken within 24 hours of injury were predictive of attention related difficulties at 1 year following injury (30) and attention related and executive functioning problems at a median time of 3 years following injury (41). One study predicted children that survived compared to those that died but could not discriminate good or worse outcomes amongst survivors (29).

Limitations: The use of NSE is limited by the abundance of NSE expressed in red blood cells and platelets making the process of haemolysis a significant source of crosscontamination when measured in trauma (43). Another limitation is the slow elimination from plasma leading to difficulties in distinguishing between primary and secondary insults to the brain.

Conclusion: Serum NSE levels are significantly higher in children with TBI including children with inflicted and non-inflicted injury and there is evidence that higher levels are associated with increasing severity of TBI. There is mixed evidence that NSE levels are associated with abnormal CT findings. The longer time to peak NSE levels in infants with inflicted injury may reflect severity of the primary injury or increased secondary injury due to a delay in seeking medical care. NSE shows promise as a predictor of outcome (GOS) at hospital discharge, 6 months and 12 months following injury with prediction of short- and long-term attention-related and executive functioning problems.

\section{Glial fibrillary acidic protein (GFAP)}

GFAP is an astrocyte specific cytoskeleton protein and is a well established marker of glial damage in severe TBI (43). 


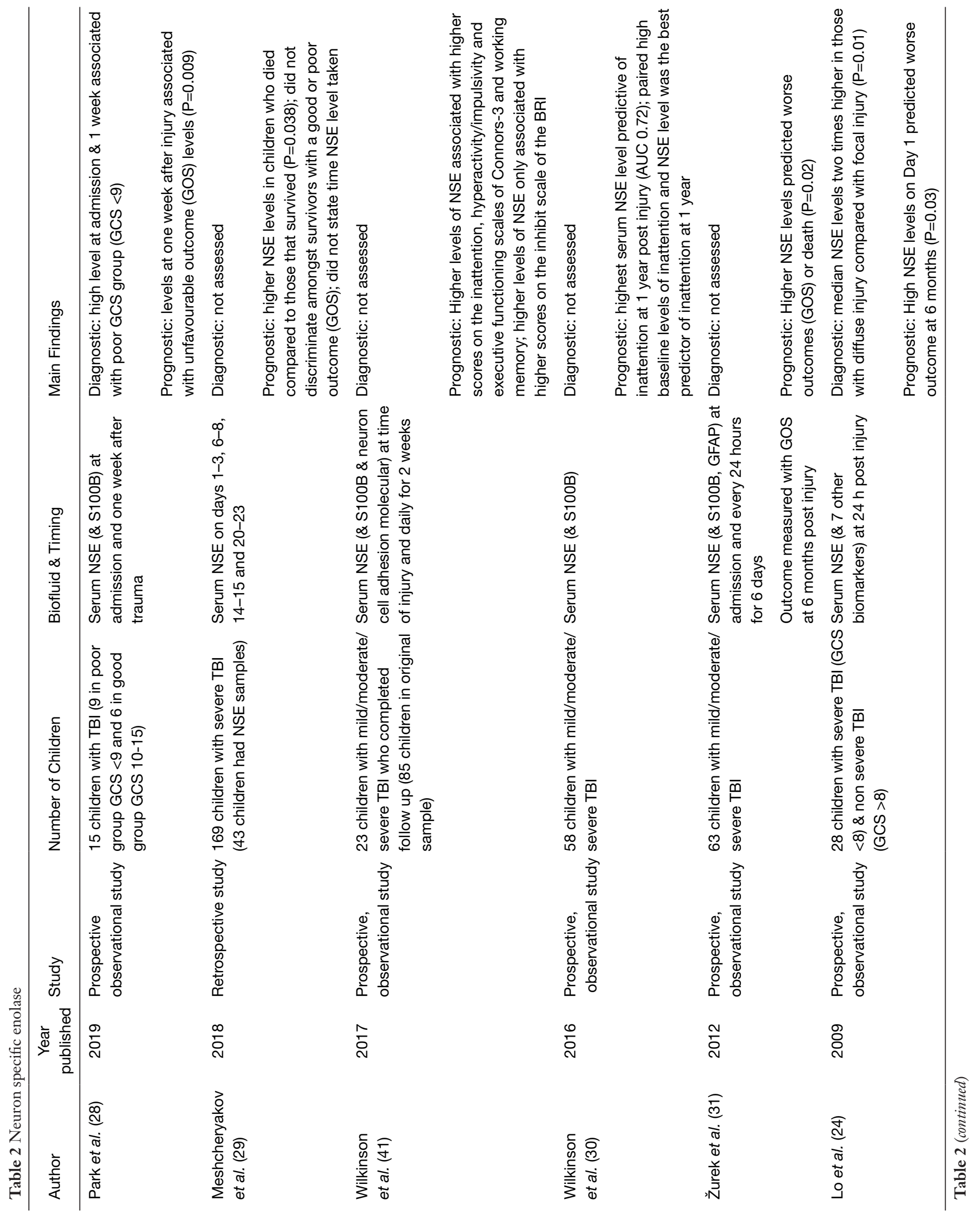




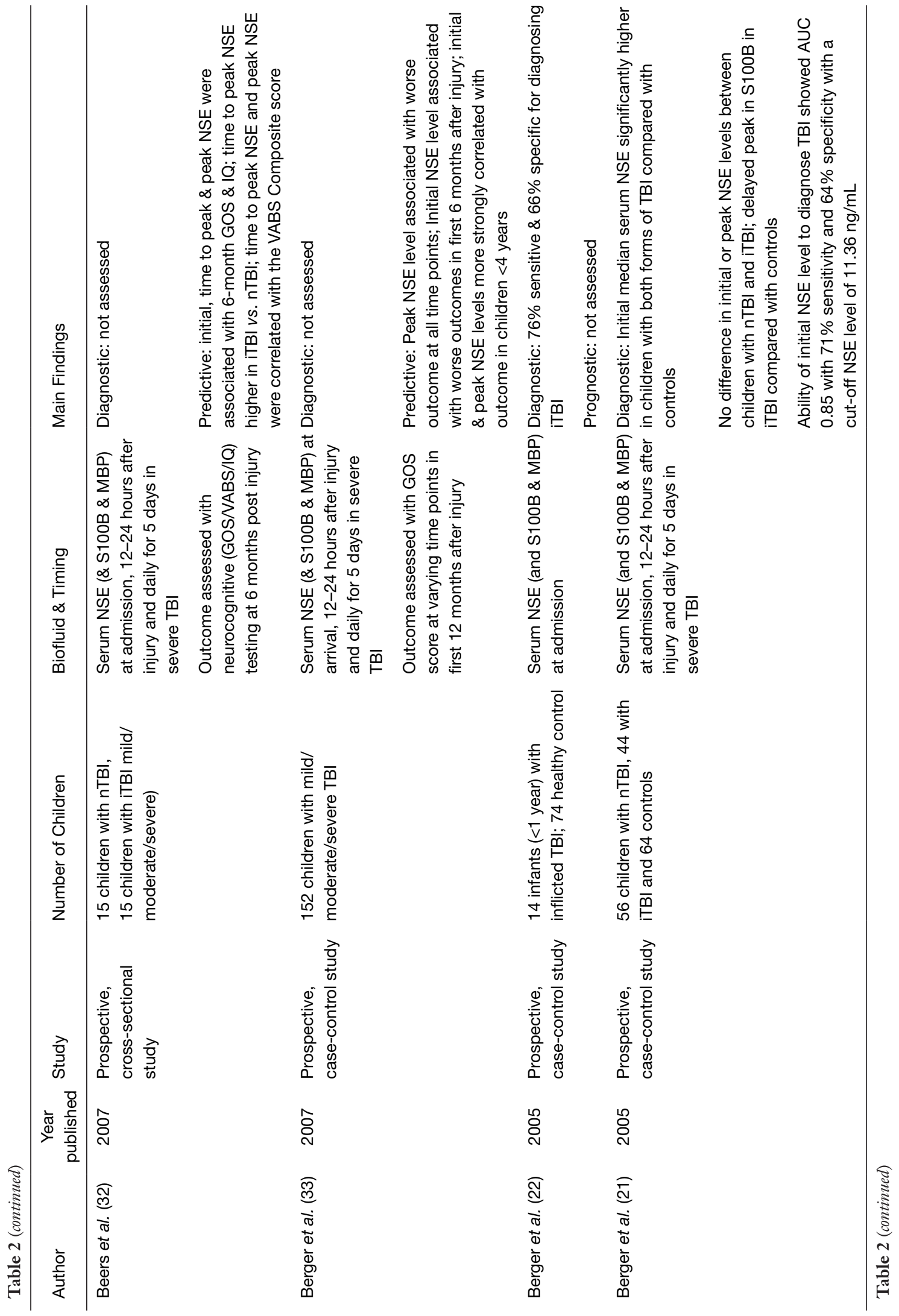




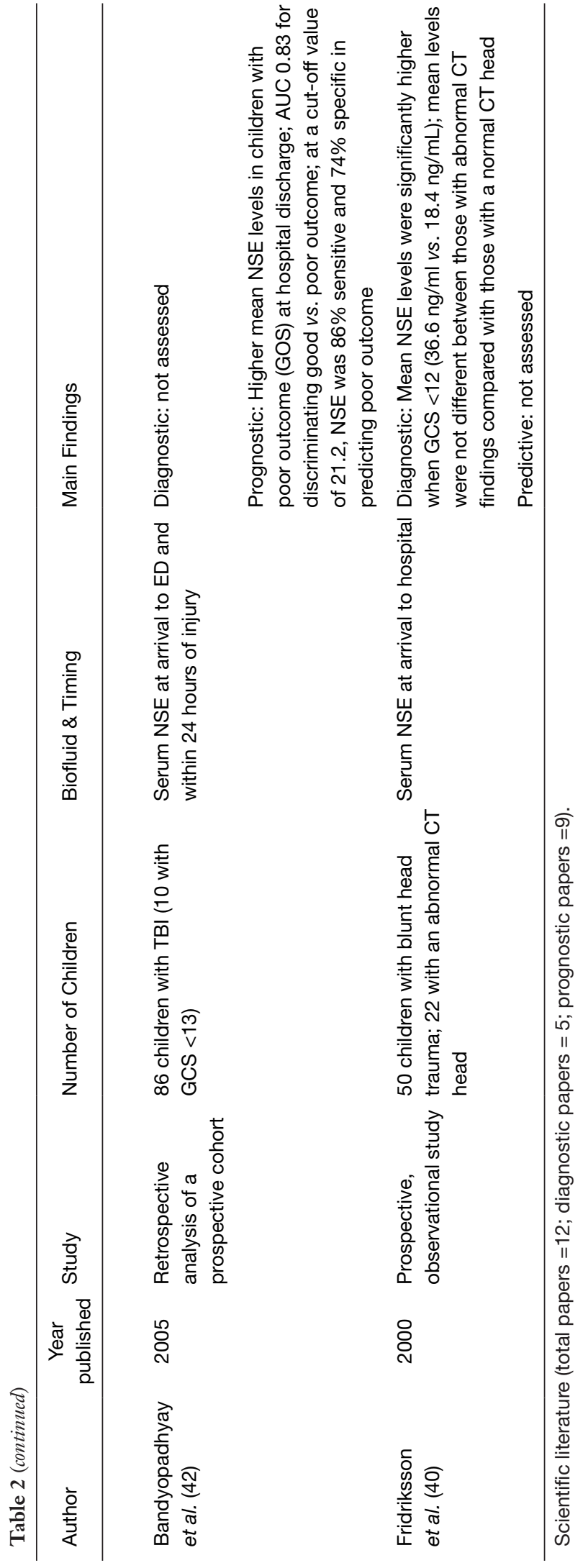

GFAP biomarker levels are elevated within 3-34 hours in serum/plasma following severe TBI (16).

Diagnostic Uses: There are 3 studies that have examined the diagnostic utility of GFAP $(31,44,45)$ (Table 3). In one casecontrol study, serum GFAP levels were significantly higher in children with TBI compared to healthy controls (44). Serum GFAP concentrations measured on arrival could discriminate between mild and severe TBI in one study (44) but were unable to discriminate TBI severity in two studies $(31,45)$. Serum GFAP on arrival also failed to correlate with physiological variables, highest intracranial pressure or with indices of injury measured on CT head (45).

Prognostic uses: There are 3 studies that have examined the prognostic utility of GFAP $(31,44,45)$ (Table 3). Serum GFAP concentrations measured on arrival were associated with worse outcomes at 6 months post injury $(31,44,45)$.

Summary: The evidence supporting the use of serum GFAP as a diagnostic tool is limited but shows promise in the prediction of outcomes at 6 months after injury.

\section{Myelin basic protein}

Myelin basic protein is an oligodendrocyte protein and is a critical constituent of the insulating myelin sheath covering axons. Myelin basic protein maintains the correct structure of myelin, interacting with the lipids in the myelin membrane (46). Though also present in the peripheral nervous system, MBP exists predominantly in the central nervous system. The process of myelination is agedependent and progresses from infancy into adolescence and degrees of myelinated axonal injury may thus differ in relation to patient age (47). Serum MBP concentrations peak 48 to 72 hours after injury and remain increased for up to 2 weeks (48).

Diagnostic Uses: Two studies have examined the diagnostic utility of MBP $(21,22)$ (Table 4). Initial serum MBP levels were not different between inflicted and noninflicted TBI (22) and were not able to discriminate between inflicted and non-inflicted TBI or controls (21). One study showed that peak MBP levels were higher in children with an intracranial haemorrhage on CT scan compared with children without intracranial haemorrhage and controls when these two groups were analysed together (21). There was a delay in peak MBP levels in children with iTBI when compared to children with nTBI (21)

Prognostic uses: There are 2 studies that have examined the prognostic utility of MBP $(32,33)$ (Table 4). One found that a high peak MBP level was predictive of worse neurocognitive outcome (32) at 6 months post injury and 
Table 3 Glial fibrillary acidic protein

\begin{tabular}{|c|c|c|c|c|c|}
\hline Author & $\begin{array}{c}\text { Year } \\
\text { published }\end{array}$ & Study & $\begin{array}{l}\text { Number of } \\
\text { children }\end{array}$ & Biofluid \& timing & Main findings \\
\hline \multirow[t]{2}{*}{$\begin{array}{l}\text { Mondello } \\
\text { et al. (44) }\end{array}$} & 2016 & Case-Control & $\begin{array}{l}45 \text { cases } / 40 \\
\text { healthy controls }\end{array}$ & $\begin{array}{l}\text { Serum GFAP (and UCH-L1) on } \\
\text { arrival to hospital }\end{array}$ & $\begin{array}{l}\text { Diagnostic: increasing severity of TBI \& the possible } \\
\text { identification of brain injury not detected on CT }\end{array}$ \\
\hline & & & $\begin{array}{l}\text { Mild/moderate/ } \\
\text { severe TBI }\end{array}$ & & Predictive: predict outcome at 6 months (GOS) \\
\hline $\begin{array}{l}\text { Žurek } \\
\text { et al. (31) }\end{array}$ & & & & $\begin{array}{l}\text { Outcome measured with GOS } \\
\text { at } 6 \text { months post injury }\end{array}$ & $\begin{array}{l}\text { Prognostic: higher GFAP levels predicted worse } \\
\text { outcomes (GOS) or death }(\mathrm{P}=0.002)\end{array}$ \\
\hline $\begin{array}{l}\text { Fraser } \\
\text { et al. (45) }\end{array}$ & 2011 & & $\begin{array}{l}27 \text { children with } \\
\text { severe TBI }\end{array}$ & $\begin{array}{l}\text { Serum GFAP at admission and } \\
\text { daily until arterial line removed. }\end{array}$ & $\begin{array}{l}\text { Diagnostic: did not correlate with clinical symptoms, } \\
\text { physiological variables or high ICP or abnormal CT } \\
\text { findings }\end{array}$ \\
\hline
\end{tabular}

Scientific literature (total papers $=3$; diagnostic papers $=3$; prognostic papers $=3$ ).

Table 4 Myelin basic protein

\begin{tabular}{|c|c|c|c|c|c|}
\hline Author & $\begin{array}{l}\text { Year } \\
\text { published }\end{array}$ & Study & Number of children & Biofluid \& timing & Main findings \\
\hline \multirow[t]{2}{*}{$\begin{array}{l}\text { Berger } \\
\text { et al. (33) }\end{array}$} & 2007 & $\begin{array}{l}\text { Prospective, } \\
\text { observational }\end{array}$ & $\begin{array}{l}152 \text { children with } \\
\text { mild/moderate/ } \\
\text { severe TBI }\end{array}$ & $\begin{array}{l}\text { Serum MBP ( } \& \text { S100B \& NSE) } \\
\text { at arrival, 12-24 hours after } \\
\text { injury and daily for } 5 \text { days in } \\
\text { severe TBI; }\end{array}$ & Diagnostic: not assessed \\
\hline & & & & $\begin{array}{l}\text { outcome assessed with GOS } \\
\text { score at varying time points } \\
\text { in first } 12 \text { months after injury }\end{array}$ & $\begin{array}{l}\text { Predictive: Peak MBP level associated with worse } \\
\text { outcome at all time points; Initial MBP level } \\
\text { associated with worse outcome in first } 3 \text { months } \\
\text { after injury; peak MBP levels more strongly } \\
\text { correlated with outcome than initial MBP levels in } \\
\text { children }<4 \text { years }\end{array}$ \\
\hline $\begin{array}{l}\text { Beers } \\
\text { et al. (32) }\end{array}$ & 2007 & $\begin{array}{l}\text { Prospective, } \\
\text { cross-sectional } \\
\text { study }\end{array}$ & $\begin{array}{l}15 \text { children with } \\
\mathrm{nTBI}, 15 \text { children } \\
\text { with iTBI (mild } \\
\text { /moderate/severe) }\end{array}$ & $\begin{array}{l}\text { Serum MBP ( } \& \text { S100B \& NSE) } \\
\text { at admission, 12-24 hours } \\
\text { after injury and daily for } \\
5 \text { days in severe TBI }\end{array}$ & Diagnostic: not assessed \\
\hline \multirow[t]{2}{*}{$\begin{array}{l}\text { Berger } \\
\text { et al. (21) }\end{array}$} & 2005 & $\begin{array}{l}\text { Prospective, } \\
\text { case-control } \\
\text { study }\end{array}$ & $\begin{array}{l}56 \text { children with } \\
\text { nTBI, } 44 \text { with iTBI } \\
\text { and } 64 \text { controls }\end{array}$ & $\begin{array}{l}\text { Serum MBP (and S100B \& } \\
\text { NSE) at admission, 12-24 } \\
\text { hours after injury and daily for } \\
5 \text { days in severe TBI }\end{array}$ & $\begin{array}{l}\text { Diagnostic: No difference in initial MBP between } \\
\text { both forms of TBI and controls }\end{array}$ \\
\hline & & & & & $\begin{array}{l}\text { Peak MBP levels higher in children with ICH }(0.33 \\
\text { vs. } 0.17 ; \mathrm{P}=0.005 ; \text { AUC } 0.69 \text { with sensitivity }(44 \%) \\
\text { and specificity }(96 \%) \text {; no difference between } \\
\text { children with iTBI compared with nTBI }\end{array}$ \\
\hline
\end{tabular}

Table 4 (continued) 
Table 4 (continued)

\begin{tabular}{lllll}
\hline Author & $\begin{array}{l}\text { Year } \\
\text { published }\end{array}$ & Study & Number of children Biofluid \& timing & Main findings \\
\hline $\begin{array}{llll}\text { Berger } \\
\text { et al. (22) }\end{array}$ & & $\begin{array}{l}\text { Prospective, } \\
\text { case-control } \\
\text { study }\end{array}$ & $\begin{array}{l}14 \text { infants (<1 year) Serum MBP (and S100B \& } \\
\text { with inflicted TBI; } \\
74 \text { healthy control }\end{array}$ & $\begin{array}{l}\text { Diagnostic: } 36 \% \text { sensitive \& 100\% specific for } \\
\text { diagnosing iTBI }\end{array}$ \\
& & & Prognostic: not assessed \\
\hline
\end{tabular}

Scientific literature (total papers $=4$; diagnostic papers $=2$ and prognostic papers $=2$ ).

the other at varying time points in the next 12 months after injury (33).

Summary: Interest in MBP has lessened in comparison to S100B, NSE and GFAP in large part due to an observed lack of clinical sensitivity but may have potential for predicting 6 month outcomes.

\section{Ubiquitin C-terminal Hydrolase-L1 (UCH-L1)}

$\mathrm{UCH}-\mathrm{L} 1$ is an E2 ubiquitin-conjugating enzyme expressed in neurons where it functions to add and remove ubiquitin to proteins intended for degradation (49). It is found almost exclusively in the cytoplasm of neurons (50).

Diagnostic Uses: There are 3 studies that have examined the diagnostic utility of serum UCH-L1 $(37,44,51)$ (Table 5). One showed that serum levels of UCH-L1 were significantly higher in children with TBI when compared to controls (51) and two found that UCH-L1 could discriminate between severe and moderate TBI $(44,51)$. However one study found that UCH-L1 could not discriminate between mild TBI and controls (37). Serum UCH-L1 levels was not associated with either clinical symptoms or abnormal CT findings.

Prognostic uses: There are 2 studies that have examined the prognostic utility of serum UCH-L1 $(37,44)$ (Table 5). One showed an elevated UCH-L1 at admission was associated with worse outcomes at 6 months (44) and one at three different time points within one year from injury on the GOS (37).

Summary: Serum UCH-L1 is one of the newest proposed biomarkers for TBI and there is currently limited data available. Serum UCH-L1 shows promise as both a diagnostic and prognostic marker of TBI in children.

\section{$\alpha-I I-S p e c t r i n$}

$\alpha$-II Spectrin is a cytoskeletal protein primarily found in neuronal axons and dendrites. This protein is broken down into spectrin breakdown products (SBDP) of differing molecular weights $(120,145,150 \mathrm{kDa})$. SBDP145, formed by calpain-mediated cleavage of spectrin, is a marker of necrotic cell death process activation.

Diagnostic Uses: There are 2 studies that have examined the diagnostic utility of SBDP145 $(37,51)$ (Table 6). These studies showed that the level at arrival and within 12 hours after injury was significantly higher when compared with controls but could not discriminate between brain injury severity. The level was also not associated with clinical symptoms or an abnormal CT scan (37).

Prognostic uses: One study examined the predictive utility of SBDP145 (37) (Table 6). This study showed that SBDP145 on arrival to hospital was associated with worse outcomes at 3 different time points within one year from injury.

Summary: The breakdown products of $\alpha$-II Spectrin are newly proposed biomarkers for TBI and as a result there are limited data available. These markers show promise as both a diagnostic and prognostic marker of TBI in children.

\section{Tau protein}

The tau proteins are a group of six highly soluble protein isoforms that have roles primarily in maintaining the stability of microtubules in axons (52). Although tau is present in dendrites at low levels, it is active primarily in the distal portions of axons. Tau proteins are abundant in the neurons of the central nervous system and they are also expressed in very low levels in CNS astrocytes and oligodendrocytes. An elevated serum tau level is indicative of axonal injury (52).

There is one study in paediatric TBI that investigated the diagnostic utility of serum tau protein (Table 7) (52). This group measured serum total tau in 416 healthy children to generate age-related normative values. The investigators used these normative data to interpret serum total tau in 158 children with TBI. The study found that on Day 1 of TBI, median serum concentrations of total tau were three times higher in children with any reduction in GCS compared with normal GCS controls. This finding 
Table 5 Ubiquitin C-Terminal Hydrolase-L1

\begin{tabular}{|c|c|c|c|c|c|}
\hline Author & $\begin{array}{c}\text { Year } \\
\text { published }\end{array}$ & Study & Number of children & Biofluid \& timing & Main findings \\
\hline \multirow[t]{2}{*}{$\begin{array}{l}\text { Metzger } \\
\text { et al. (51) }\end{array}$} & 2018 & $\begin{array}{l}\text { Prospective, } \\
\text { observational with } \\
\text { control samples }\end{array}$ & $\begin{array}{l}19 \text { children with } \\
\text { severe TBI matched } \\
\text { to } 4 \text { controls }\end{array}$ & $\begin{array}{l}\text { Serum UCH-L1 (and SBDP-145) } \\
\text { at 12, 24, 72, } 96 \text { and } 120 \text { hours }\end{array}$ & $\begin{array}{l}\text { Diagnostic: increased levels over } \\
\text { controls; peak at } 12 \text { hours and baseline } \\
\text { levels at } 120 \text { hours }\end{array}$ \\
\hline & & & & & Predictive: not assessed \\
\hline $\begin{array}{l}\text { Mondello } \\
\text { et al. (44) }\end{array}$ & & & $\begin{array}{l}\text { Mild/moderate/ } \\
\text { severe TBI }\end{array}$ & $\begin{array}{l}\text { Outcome measured at } 6 \text { months } \\
\text { (GOS) }\end{array}$ & $\begin{array}{l}\text { Predictive: predict outcome at } \\
6 \text { months (GOS) }\end{array}$ \\
\hline \multirow[t]{2}{*}{$\begin{array}{l}\text { Berger } \\
\text { et al. (37) }\end{array}$} & 2012 & $\begin{array}{l}\text { Prospective, } \\
\text { observational }\end{array}$ & $\begin{array}{l}39 \text { cases with mild/ } \\
\text { moderate/severe TBI } \\
\text { and } 10 \text { controls }\end{array}$ & $\begin{array}{l}\text { Serum UCH-L1 on arrival to } \\
\text { hospital }\end{array}$ & $\begin{array}{l}\text { Diagnostic: increased levels in } \\
\text { moderate and severe TBI but not mild } \\
\text { compared to controls }\end{array}$ \\
\hline & & & & & Predictive: predicted worse outcomes \\
\hline
\end{tabular}

Scientific literature (total papers $=3$; diagnostic papers $=3$; prognostic papers $=2$ ).

Table 6 Alpha II-spectrin

\begin{tabular}{|c|c|c|c|c|c|}
\hline Author & $\begin{array}{c}\text { Year } \\
\text { published }\end{array}$ & Study & Number of Children & Biofluid & Main Findings \\
\hline \multirow[t]{2}{*}{$\begin{array}{l}\text { Metzger } \\
\text { et al. (51) }\end{array}$} & 2018 & $\begin{array}{l}\text { Prospective, } \\
\text { observational }\end{array}$ & $\begin{array}{l}19 \text { children with severe TBI } \\
\text { matched to } 4 \text { controls }\end{array}$ & $\begin{array}{l}\text { Serum SBDP-145 (and UCH-L1) } \\
\text { at } 12,24,72,96 \text { and } 120 \text { hours }\end{array}$ & $\begin{array}{l}\text { Diagnostic: increased levels over } \\
\text { controls; peak at } 48 \text { hours and } \\
\text { remaining high at } 120 \text { hours }\end{array}$ \\
\hline & & & & & Predictive: not assessed \\
\hline $\begin{array}{l}\text { Berger } \\
\text { et al. (37) }\end{array}$ & & & & $\begin{array}{l}\text { Outcome measured as GOS at } \\
\text { hospital discharge, } 3-4 \text { months } \\
\text { and } 6-8 \text { months after discharge }\end{array}$ & $\begin{array}{l}\text { Not diagnostic of clinical symptoms } \\
\text { or abnormal CT head. }\end{array}$ \\
\hline
\end{tabular}

Scientific literature (total papers $=2$; diagnostic papers $=2$; prognostic paper $=1$ )

Table 7 Total Tau Protein

\begin{tabular}{|c|c|c|c|c|c|}
\hline Author & Year published & Study & Number of children & Biofluid & Main findings \\
\hline
\end{tabular}

Scientific literature (total papers $=1$; diagnostic papers $=1$; prognostic papers $=0$ ). 
Table 8 Secondary brain injury

\begin{tabular}{|c|c|c|c|c|c|}
\hline Author & $\begin{array}{c}\text { Year } \\
\text { published }\end{array}$ & Study & Number of children & Biofluid \& timing & Main findings \\
\hline \multicolumn{6}{|l|}{ IL-6 } \\
\hline \multicolumn{6}{|l|}{ SNCAM } \\
\hline \multirow[t]{2}{*}{$\begin{array}{l}\text { Wilkinson } \\
\text { et al. (41) }\end{array}$} & 2017 & $\begin{array}{l}\text { Prospective } \\
\text { observational } \\
\text { study }\end{array}$ & $\begin{array}{l}23 \text { children with mild/ } \\
\text { moderate/severe TBI who com- } \\
\text { pleted follow up } \\
\text { ( } 85 \text { children in original sample) }\end{array}$ & $\begin{array}{l}\text { Neuron cell adhesion } \\
\text {-molecular) at time of injury } \\
\text { and daily for } 2 \text { weeks }\end{array}$ & Diagnostic: not assessed \\
\hline & & & & & $\begin{array}{l}\text { Prognostic: Lower levels of sNCAM } \\
\text { were associated with higher scores } \\
\text { on inattention, hyperactivity/ } \\
\text { impulsivity and executive functioning } \\
\text { scales and working memory }\end{array}$ \\
\hline
\end{tabular}

sNCAM, sE-Selectin, soluble intercellular adhesion molecule, soluble vascular cell adhesion molecule, IL6, IL-8

$\begin{array}{ll}\text { Wilkinson } 2016 & \begin{array}{l}\text { Prospective } 58 \text { children with mild/ } \\ \text { observational moderate/severe TBI } \\ \text { et al. (30) }\end{array} \\ \text { study }\end{array}$

Heat shock proteins (Hsp)

Žurek 2012 Prospective, 63 children with mild/ et al. (31) observational moderate/severe TBI study

\section{IL-6, IL-8, IL-10, L-selectin. SICAM, endothelin}

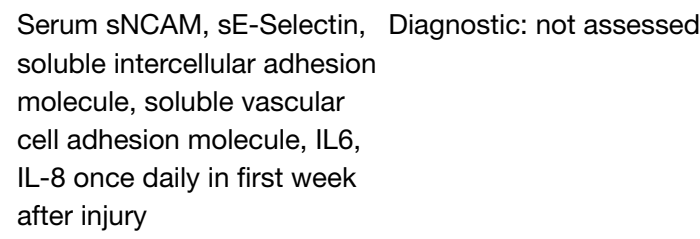

Prognostic: the highest serum level of sE-selectin (AUC =0.71) and trough serum levels of SNCAM (AUC $=0.75$ ) were the highest predictors of inattention at 1 year post-injury

Hsp at admission and every Diagnostic: not assessed 24 hours for 6 days

Outcome measured with Prognostic: Hsp not related to GOS at 6 months post injury outcome

Biomarker levels at $24 \mathrm{~h}$ post injury
Diagnostic: Only IL-6 $(\mathrm{P}=0.02)$ and SICAM $(P=0.01)$ were significantly higher in children with severe injury than those with non-severe injury

Prognostic: High L-selectin, IL-6 and IL-8 levels predicted worse outcome at 6 months 
supported total tau as a marker of injury, however, there was a poor association with injury severity and abnormalities on CT scan images.

\section{Secondary brain injury: biomarkers of cellular, biochemical \& molecular cascades}

Biomarkers reflecting aspects of the cellular, biochemical, or molecular cascades in the secondary brain injury response have been investigated to a lesser extent in children. The secondary injury biomarkers that have been investigated to date include IL-6, IL-8, 1L-10, L-selectin, sE-selectin, endothelin, soluble neuron cell adhesion molecule (sNCAM), soluble intercellular adhesion molecule (SICAM), soluble vascular cell adhesion molecule and heat shock proteins (Table 8). The most studied of these secondary injury biomarkers is IL-6 and the results are inconsistent with respect to both diagnostic and prognostic utility (53).

\section{Primary \& secondary brain injury: using paired or multiple biomarkers}

Serum levels of most acute TBI biomarkers return to baseline levels within days to a week following TBI. However, the subacute and chronic effects of TBI can persist for months following the initial injury event. Thus, it may be appropriate to consider a continuum of TBI biomarkers that may be released at different time points following the initial brain injury event. Given the failure to find a single biomarker that satisfies all the criteria of an "ideal" biomarker in severe TBI, some investigators have examined combinations of biomarkers.

A prospective observational study was conducted in 28 children who had an arterial blood sample taken exactly at 24 hours post-injury (24). Serum concentrations of 8 different biomarkers-S100b, NSE, IL-6, IL-8, IL-10, soluble intracellular adhesion molecule (SICAM), L-selectin and endothelin-were quantified. Global outcome was assessed at 6 months post-injury using the Glasgow Outcome Score. None of the 8 biomarkers assessed individually achieved an AUC of more than 0.95 for predicting unfavourable outcome, but 5 of the 20 biomarker pairs assessed, had a high degree of outcome predictability. The primary brain injury biomarker pair that achieved the highest AUC was the combination of S100B with NSE. An $\mathrm{S} 100 \mathrm{~B}>0.04 \mathrm{ng} / \mathrm{mL}$ and NSE $\geq 10 \mathrm{mg} / \mathrm{mL}$ achieved an AUC 0.97 with $100 \%$ sensitivity and $92 \%$ specificity for the prediction of unfavourable outcome.
In that same study (24), two combinations using S100B and either L-selectin or IL-6 achieved an AUC of 0.98 and their specificity and sensitivity for unfavourable outcome prediction was $96 \%$ and $100 \%$ respectively. Their conclusion was that prognostic pairs combining serum levels of two biomarkers (brain proteins and inflammatory mediators) offer better outcome predictive values for unfavourable outcome after childhood brain trauma than may be achieved using individual marker levels.

A study by Wilkinson et al. (30) showed that the best predictors of inattention at 1 year following injury in 58 children with varying degrees of TBI were a combination of secondary brain injury biomarkers. In the two-variable ROC model, combinations of baseline levels of inattention with four biomarkers individually improved the model. The AUCs for combinations of baseline levels of inattention with trough serum levels of sNCAM and with highest serum levels of sE-selectin, S100b and NSE were 0.86, 0.87, 0.90 and 0.94 , respectively.

\section{Future directions}

This review highlights the obstacles impeding the interpretation and generalisability of biomarker data. These obstacles include a wide variability in the patient cohort, clinical characteristics, study methodology and diagnostic and prognostic variables used as outcome measures. Nonetheless, serum S100B and serum NSE levels show promise as a diagnostic tool with biomarker levels significantly higher in children with severe TBI including children with inflicted and non-inflicted head injury. Serum S100B and serum NSE also show promise as a predictor of neurodevelopmental outcome.

In order to realise the full potential of biospecimens in paediatric traumatic brain injury, standardisation and adoption of best practice guidelines are needed to ensure the quality and consistency of specimens. A workgroup was formed in 2012 to specifically address this gap. The aim of the Pediatric TBI CDE Biospecimens and Biomarkers Workgroup was to provide recommendations for best practice guidelines to standardise the quality and accessibility of biospecimens for paediatric brain injury research (54). Consensus recommendations were developed and represent expert opinion on this subject. It is the hope that future investigators will be able to obtain biospecimens in a consistent way that will ease data interpretation on biomarker potential in clinical practice.

Blood biomarkers are entering clinical use for adult 
patients with TBI, with the introduction of S100B to the 2013 Scandinavian Guidelines (55) and the 2018 US Federal Drug Administration's approval of GFAP and UCH-L1 for reducing the unnecessary use of CT head scans to help detect concussion in adults, the ALERT-TBI study (56). The Brain Trauma Indicator test measures two biomarkers: GFAP and UCH-L1 taken within 12 hours of injury and results returned to the clinician within 3-4 hours to aid decision making (57). The introduction of a blood biomarker into paediatric practice is not currently on the horizon, given the lack of current evidence for diagnostic and prognostic utility.

\section{Conclusions}

To date, no biomarker with sufficient sensitivity and specificity has been validated as a clinical tool in paediatric patients with severe TBI. Serum S100B and serum NSE levels show promise as a diagnostic tool with biomarker levels significantly higher in children with severe TBI including children with inflicted and non-inflicted head injury. Serum S100B and serum NSE also show promise as a predictor of neurodevelopmental outcome.

Further research is needed with standardisation of methodology and outcome variables with potential utility in the combination of biomarkers that measure and assess both primary and secondary brain injury.

\section{Acknowledgments}

Funding: None.

\section{Footnote}

Provenance and Peer Review: This article was commissioned by the Guest Editors (Jan Hau Lee, Vijay Srinivasan, and Debbie Long) for the series "Pediatric Critical Care" published in Translational Pediatrics. The article has undergone external peer review.

Peer Review File: Available at https://dx.doi.org/10.21037/ tp-20-386

Conflicts of Interest: Both authors have completed the ICMJE uniform disclosure form (available at https://dx.doi. org/10.21037/tp-20-386). The series "Pediatric Critical Care" was commissioned by the editorial office without any funding or sponsorship. The authors have no other conflicts of interest to declare.

Ethical Statement: The authors are accountable for all aspects of the work in ensuring that questions related to the accuracy or integrity of any part of the work are appropriately investigated and resolved.

Open Access Statement: This is an Open Access article distributed in accordance with the Creative Commons Attribution-NonCommercial-NoDerivs 4.0 International License (CC BY-NC-ND 4.0), which permits the noncommercial replication and distribution of the article with the strict proviso that no changes or edits are made and the original work is properly cited (including links to both the formal publication through the relevant DOI and the license). See: https://creativecommons.org/licenses/by-nc-nd/4.0/.

\section{References}

1. Centres for Disease Control and Prevention (2019). Surveillance Report of Traumatic Brain Injury-related Emergency Department Visits, Hospitalizations, and Deaths - United States, 2014. Centers for Disease Control and Prevention, U.S. Department of Health and Human Services.

2. Martinez BI, Stabenfeldt SE. Current trends in biomarker discovery and analysis tools for traumatic brain injury. J Biol Eng 2019;13:16.

3. Galgano M, Toshkezi G, Qui X, et al. Traumatic Brain Injury. Current Treatment Strategies and Future Endeavors. Cell Transplant 2017;26:1118-30.

4. Kinoshita K. Traumatic brain injury: pathophysiology for neurocritical care. J Intensive Care 2016;4:29.

5. Kochanek PM, Tasker RC, Carney N, et al. Guidelines for the Management of Pediatric Severe Traumatic Brain Injury, Third Edition: Update of the Brain Trauma Foundation Guidelines. Neurosurgery 2019;84:1169-78.

6. Carney NA, Chesnut R, Kochanek PM, et al. Guidelines for the acute medical management of severe traumatic brain injury in infants, children, and adolescents. Pediatr Crit Care Med 2003;4:S1.

7. Kochanek PM, Carney N, Adelson PD, et al. Guidelines for the Acute Medical Management of Severe Traumatic Brain Injury in Infants, Children, and Adolescents Second Edition. Pediatr Crit Care Med 2012;13 Suppl 1:S1-82. Erratum in: Pediatr Crit Care Med 2012;13:252.

8. Hutchison JS, Ward RE, Lacroix J, et al. Hypothermia Pediatric Head Injury Trial Investigators and the Canadian 
Critical Care Trials Group: Hypothermia therapy after traumatic brain injury in children. $\mathrm{N}$ Engl J Med 2008;358:2447-56.

9. Adelson PD, Wisniewski SR, Beca J, et al. Paediatric Traumatic Brain Injury Consortium: Comparison of hypothermia and normothermia after severe traumatic brain injury in children (Cool Kids): A phase 3, randomised controlled trial. Lancet Neurol 2013;12:546-53.

10. Beca J, McSharry B, Erickson S, et al. Hypothermia for Traumatic Brain Injury in Children - A Phase II Randomized Controlled Trial. Crit Care Med 2015;43:1458-66.

11. Califf RM. Biomarker definitions and their applications. Exp Biol Med (Maywood) 2018;243:213-21.

12. FDA-NIH Biomarker Working Group. BEST (Biomarkers, EndpointS and other Tools) Resource. Silver Spring (MD): Food and Drug Administration (US); Bethesda (MD): National Institutes of Health (US). 2016.

13. Papa L, Ramia MM, Kelly JM, et al. Systematic Review of Clinical Research on Biomarkers for Pediatric Traumatic Brain Injury. J Neurotrauma 2013;30:324-38.

14. Yeung C, Bhatia R, Bhattarai B, et al. Role of Salivary Biomarkers in Predicting Significant Traumatic Brain Injury: An Exploratory Study. Pediatr Emerg Care 2020. doi:10.1097/ PEC.0000000000002050. [Epub ahead of print].

15. Janigro D, Bailey DM, Lehmann S, et al. Peripheral Blood and Salivary Biomarkers of Blood-Brain Barrier Permeability and Neuronal Damage: Clinical and Applied Concepts. Front Neurol 2021;11:577312.

16. Vos PE, Jacobs B, Andriessen TMJC, et al. GFAP and S100B are biomarkers of traumatic brain injury. An Observational Study. Neurology 2010;75:1786-93.

17. Dadas A, Washington J, Diaz-Arrastia R, et al. Biomarkers in traumatic brain injury (TBI): a review. Neuropsychiatr Dis Treat 2018;14:2989-3000.

18. Sandler SJI, Figaji AA. Clinical Applications of biomarkers in pediatric traumatic brain injury. Childs Nerv Syst 2010;26:205-13.

19. Berger RP, Pierce MC, Wisniewski SR, et al. Serum S100B concentrations are increased after closed head injury in children: a preliminary study. J Neurotrauma 2002;19:1405-9.

20. Akhtar JI, Spear RM, Senac MO, et al. Detection of traumatic brain injury with magnetic resonance imaging and $\mathrm{S} 100 \mathrm{~B}$ protein in children, despite normal computed tomography of the brain. Pediatr Crit Care Med 2003;4:322-6.

21. Berger RP, Adelson PD, Pierce MC, et al. Serum neuron-specific enolase, $\mathrm{S} 100 \mathrm{~B}$, and myelin basic protein concentrations after inflicted and noninflicted traumatic brain injury in children. J Neurosurg 2005;103:61-8.

22. Berger RP, Dulani T, Adelson PD, et al. Identification of inflicted traumatic brain injury in well-appearing infants using serum and cerebrospinal markers: a possible screening tool. Pediatrics 2006;117:325-32.

23. Piazza O, Storti MP, Cotena S, et al. S100B is Not a Reliable Prognostic Index in Paediatric TBI. Pediatr Neurosurg 2007;43:258-64.

24. Lo TY, Jones PA, Minns RA. Pediatric Brain Trauma Outcome Prediction Using Paired Serum Levels of Inflammatory Mediators and Brain-Specific Proteins. J Neurotrauma 2009;26:1479-87.

25. Bechtel K, Frasure S, Marshall C, et al. Relationship of serum S100B levels and intracranial injury in children with closed head trauma. Pediatrics 2009; 124:e697-704.

26. Hallén M, Karlsson M, Carlhed R, et al. S-100B in Serum and Urine After Traumatic Head Injury in Children. J Trauma 2010;69:284-9.

27. Babcock L, Byczkowski T, Mookerjee S, et al. Ability of S100B to predict severity and cranial CT results in children with TBI. Brain Inj 2012;26:1372-80.

28. Park DW, Park SH, Hwang SK. Serial measurement of S100B and NSE in pediatric traumatic brain injury. Childs Nerv Syst 2019;35:343-8.

29. Meshcheryakov SV, Semenova ZB, Lukianov VI, et al. Prognosis of Severe Traumatic Brain Injury Outcomes in Children. Acta Neurochir Suppl 2018;126:11-6.

30. Wilkinson AA, Simic N, Frndova H, et al. Serum Biomarkers Help Predict Attention Problems in Critically Ill Children With Traumatic Brain Injury. Pediatr Crit Care Med 2016;17:638-48.

31. Žurek J, Fedora M. The usefulness of S100B, NSE, GFAP, NF-H, secretagogin and Hsp70 as a predictive biomarker of outcome in children with traumatic brain injury. Acta Neurochir (Wien) 2012;154:93-103.

32. Beers SR, Berger RP, Adelson PD. Neurocognitive Outcome and Serum Biomarkers in Inflicted versus NonInflicted Traumatic Brain Injury in Young Children. J Neurotrauma 2007;24:97-105.

33. Berger RP, Beers SR, Richichi R, et al. Serum biomarker concentrations and outcome after paediatric traumatic brain injury. J Neurotrauma 2007;24:1793-801.

34. Spinella PC, Dominguez T, Drott HR, et al. S100beta protein-serum levels in healthy children and its association with outcome in paediatric traumatic brain injury. Crit Care Med 2003;31:939-45. 
35. Kochanek PM, Berger RP, Bayir H, et al. Biomarkers of primary and evolving damage in traumatic and ischemic brain injury: diagnosis, prognosis, probing mechanisms, and therapeutic decision making. Curr Opin Crit Care 2008;14:135-41.

36. Forde CT, Karri SK, Young AMH, et al. Predictive markers in traumatic brain injury: opportunities for a serum biosignature. Br J Neurosurg 2014;28:8-15.

37. Berger RP, Hayes RL, Richichi R, et al. Serum Concentrations of Ubiquitin C-Terminal Hydrolase-L1 and alphaII-Spectrin Breakdown Product $145 \mathrm{kDa}$ Correlate with Outcome after Pediatric TBI. J Neurotrauma 2012;29:162-7.

38. Cheng F, Yuan Q, Yang J, et al. The prognostic value of serum neuron-specific enolase in traumatic brain injury: systematic review and meta-analysis. PLoS One 2014;9:e106680.

39. Kirino T, Brightman MW, Oertel WH, et al. Neuronspecific enolase as an index of neuronal regeneration and reinnervation. J Neurosci 1983;3:915-23.

40. Fridriksson T, Kini N, Walsh-Kelly C, et al. Serum neuron-specific enolase as a predictor of intracranial lesions in children with head trauma: a pilot study. Acad Emerg Med 2000;7:816-20.

41. Wilkinson AA, Dennis M, Simic N, et al. Brain biomarkers and pre-injury cognition are associated with long-term cognitive outcome in children with traumatic brain injury. BMC Pediatr 2017;17:173.

42. Bandyopadhyay S, Hennes H, Gorelick MH, et al. Serum Neuron-specific Enolase as a Predictor of Short-term Outcome in Children with Closed Traumatic Brain Injury. Acad Emerg Med 2005;12:732-8.

43. Toman E, Harrison S, Belli T. Biomarkers in traumatic brain injury: a review. J R Army Med Corps 2016;162:103-8.

44. Mondello S, Kobeissy F, Vestri A, et al. Serum Concentrations of Ubiquitin C-Terminal Hydrolase-L1 and Glial Fibrillary Acidic Protein after Pediatric Traumatic Brain Injury. Sci Rep 2016;6:28203.

45. Fraser DD, Close TE, Rose KL, et al. Severe traumatic brain injury in children elevates glial fibrillary acid protein in cerebrospinal fluid and serum. Pediatr Crit Care Med 2011;12:319-24.

46. Deber CM, Reynolds SJ. Central nervous system myelin: structure, function, and pathology. Clin Biochem 1991;24:113-34.

47. Su E, Bell MJ, Kochanek PM, et al. Increased CSF concentrations of myelin basic protein after TBI in infants and children: absence of significant effect of therapeutic hypothermia. Neurocrit Care 2012;17:401-7.

48. Thomas DG, Hoyle NR, Seeldrayers P. Myelin basic protein immunoreactivity in serum of neurosurgical patients. J Neurol Neurosurg Psychiatry 1984;47:173-5.

49. Tongaonkar P, Chen L, Lambertson D, et al. Evidence for an interaction between ubiquitin-conjugating enzymes and the 26S proteasome. Mol Cell Biol 2000;20:4691-8.

50. Wang KK, Yang Z, Zhu T, et al. An update on diagnostic and prognostic biomarkers for traumatic brain injury. Expert Rev Mol Diagn 2018;18:165-80.

51. Metzger RR, Sheng X, Niedzwecki CM, et al. Temporal response profiles of serum ubiquitin C-terminal hydrolase L1 and the $145-\mathrm{kDa}$ alpha II-spectrin breakdown product after severe traumatic brain injury in children. J Neurosurg Pediatr 2018;22:369-74.

52. Stukas S, Higgins V, Frndova E, et al. Charaterisation of serum total tau following paediatric traumatic brain injury: a prospective, longitudinal case-control study. Lancet Child Adolesc Health 2019;3:558-67.

53. Park SH, Hwang SK. Prognostic Value of Serum Levels of S100 Calcium-Binding Protein B, NeuronSpecific Enolase, and Interleukin-6 in Pediatric Patients with Traumatic Brain Injury. World Neurosurg 2018;118:e534-42.

54. Berger RP, Beers SR, Papa L, et al. Common Data Elements for Pediatric Traumatic Brain Injury: Recommendations from the Biospecimens and Biomarkers Workgroup. J Neurotrauma 2012;29:672-7.

55. Undén J, Ingebrigtsen T, Romner B; Scandinavian Neurotrauma Committee (SNC). Scandinavian guidelines for initial management of minimal, mild and moderate head injuries in adults: an evidence and consensus-based update. BMC Med 2013;11:50.

56. Bazarian JJ, Biberthaler P, Welch RD, et al. Serum GFAP and UCH-L1 for prediction of absence of intracranial injuries on head CT (ALERT-TBI): a multicentre observational study. Lancet Neurol 2018;17:782-9.

57. Food and Drug Administration. FDA authorizes marketing of first blood test to aid in the evaluation of concussion in adults. February 14, 2018.

Cite this article as: Ganeshalingham A, Beca J. Serum biomarkers in severe paediatric traumatic brain injury-a narrative review. Transl Pediatr 2021;10(10):2720-2737. doi: $10.21037 /$ tp-20-386 